\title{
Obesity as a risk factor for prostate cancer: A clinical review
}

\author{
Tushar Trivedi, MD, MPH ${ }^{1-3}$, Marsha Samson, PhD, MSPH, MHSA ${ }^{1-3 *}$, Olubunmi Orekoya, MD, MPH ${ }^{1-3}$ and Swathi Roy, MD $^{4}$ \\ ${ }^{1}$ Department of Epidemiology and Biostatistics, University of South Carolina, SC, USA \\ ${ }^{2}$ Cancer Prevention and Control Program, University of South Carolina, SC, USA \\ ${ }^{3}$ Arnold School of Public Health, University of South Carolina, SC, USA \\ ${ }^{4}$ Bronx Lebanon Hospital, NY, USA
}

\begin{abstract}
Epidemiological studies have shown a significant association between obesity and several cancers, but the role of obesity in prostate cancer etiology remains elusive. More recent studies somewhat clarify this complex relationship and we sought to review the data linking obesity and prostate cancer to make sense of this conflicting data. To systematically evaluate epidemiologic data available we performed a Google Scholar search with the following keywords: "obesity", "prostate cancer", "obesity and prostate cancer.” Recent prospective studies suggest obesity is associated with increased risk of aggressive prostate cancers but with a reduced risk of low-grade tumors. The etiology of the differential effect of obesity on subtypes of prostate cancer is multifactorial, and interactions between hormonal changes including sex steroids, insulin, IGF's and inflammatory mediators have been implicated. It has also been suggested that it is harder to detect prostate cancer in obese men through routine diagnostic approaches. Given the high prevalence of obesity and prostate cancer in the western world, further research to evaluate this complex relationship is warranted. Furthermore, novel approaches may be required to improve disease prostate cancer diagnosis among obese individuals.
\end{abstract}

\section{Introduction}

Obesity is an epidemic that affects approximately $33 \%$ of the United States (US) population [1]. In the US, obesity rates have increased substantially in the past three decades [2]. Obesity is associated with many chronic diseases including diabetes, hypertension, coronary artery disease $[3,4]$, and is linked to the development of numerous types of cancers [5]. Prostate cancer is the most common type of cancer and the second leading cause of cancer death among men in the US [6]. In 2014, more than 215,000 new cases of prostate cancer were diagnosed, and approximately 30,000 men died of prostate cancer [6]. Evidence for the association between obesity and prostate cancer is elusive and inconclusive. Epidemiological studies done in the past investigating the link between obesity and prostate cancer reveals mixed results. Literature search done on this topic, generate multiple articles to suggest that obesity protects, promotes or has no effect on prostate cancer [7-11]. However, more recent articles indicate obesity increases the risk of aggressive cancer but decreases the risk of indolent cancers. Therefore, to make sense out of this apparently conflicting data, we sought to review epidemiological data linking obesity and prostate cancer.

\section{Methods}

A literature search was conducted using Google Scholar for the terms "obesity", "prostate cancer", and "obesity and prostate cancer." The search was restricted to studies that were written in English, written after the year 2000, and conducted only in humans. Titles and abstracts of examined articles were reviewed and of the selected papers, reference lists were searched to identify additional articles. Relevant references and articles were reviewed. Information about study design, location, study participants, measurements, results, and main findings/ summary were extracted (Table 1) from each study $(n=12)$.

\section{Results}

A number of epidemiological studies have been done to evaluate the relation between obesity and prostate cancer. In most of the studies, body mass index (BMI) has been used as a surrogate of obesity. BMI is calculated by dividing weight $(\mathrm{kg})$ and height $\left(\mathrm{m}^{2}\right)$. Nomura et al. reviewed 12 case-control studies and 11 cohort studies published from 1984 to 2000 [7]. He concluded that results were mixed, and the evidence is inconclusive. In 2006, McInnis et al. reviewed 31 cohort studies and 25 case-control studies from 1966 to 2004, which concluded that obesity was associated with weak yet significant, increased prostate cancer risk [8]. Following prospective cohort studies [9-12] and case-control studies [13-15] found no association between prostate cancer and obesity. A large prospective study, which included 950,000 participants who were followed for an average of 21 years, reported relative risk (RR) of 1.09 (95\% CI:1.04-1.15) for prostate cancer among obese men. However, the risk was much higher in those who were obese at age 45 years $[R R=1.58$ (95\% CI:1.29-1.94)]. The study confirmed 33,300 cases of prostate cancer during follow-up [16].

Recent study found an inverse relation between obesity and prostate cancer risk, but only for those under 60 years of age or with a family history of cancer [17]. Collectively these studies point towards obesity having a modest positive effect on prostate cancer risk but conflicting results makes the interpretation difficult and inconclusive.

A much clearer picture emerges from recent studies which examined the relation between obesity and prostate cancer by incidence, grade, and mortality. Though the link between obesity and prostate cancer

Correspondence to: Marsha Samson, Department of Epidemiology and Biostatistics, Arnold School of Public Health, University of South Carolina, 800 Sumter Street, Columbia, SC 29208, USA, Tel: 786877 7287; E-mail: msamson@email.sc.edu

Key words: obesity, prostate cancer, diagnosis, grade

Received: Janaury 22, 2016; Accepted: February 08, 2016; Published: February 11,2016 
Table 1. Summary of studies of obesity and prostate cancer.

\begin{tabular}{|c|c|c|c|c|c|}
\hline Study, reference number, year & Study design & Population & Measurements & Results & Summary \\
\hline $\begin{array}{l}\text { Schuurman [9] } \\
(2000)\end{array}$ & Cohort & $\begin{array}{l}\text { Netherlands } \\
58,279 \text { participants } \\
681 \text { cases }\end{array}$ & $\begin{array}{l}\text { BMI* } \\
\text { LBM* } \\
\text { Height }\end{array}$ & $\begin{array}{l}\mathrm{RR}^{*}=0.9(\mathrm{NS} *) \\
\mathrm{RR}=1.0(\mathrm{NS}) \\
\mathrm{RR}=1.0(\mathrm{NS})\end{array}$ & $\begin{array}{l}\text { No clear association for advanced stage } \\
\text { Prostate cancer. BMI at a young age had } \\
\text { a positive association. }\end{array}$ \\
\hline $\begin{array}{l}\text { Habel }[10] \\
(2000)\end{array}$ & Cohort & $\begin{array}{l}\text { US. California } \\
70,712 \text { participants } \\
2.079 \text { cases }\end{array}$ & $\begin{array}{l}\text { BMI } \\
\text { Weight } \\
\text { Height }\end{array}$ & $\begin{array}{l}\mathrm{RR}=0.9(\mathrm{NS}) \\
\mathrm{RR}=1.1(\mathrm{NS}) \\
\mathrm{RR}=1.1(\mathrm{NS})\end{array}$ & $\begin{array}{l}\text { No significant associationbetween } \\
\text { anthropometric measures and Prostate } \\
\text { cancer }\end{array}$ \\
\hline $\begin{array}{l}\text { Lee }[11] \\
(2001)\end{array}$ & Cohort & $\begin{array}{l}\text { US. } \\
8,922 \text { participants } \\
439 \text { cases }\end{array}$ & $\begin{array}{l}\text { BMI } \\
\text { Waist girth } \\
\text { PA* }\end{array}$ & $\begin{array}{l}\mathrm{RR}=1.02(\mathrm{NS}) \\
\mathrm{RR}=1.04(\mathrm{NS}) \\
\mathrm{RR}=1.19(\mathrm{NS})\end{array}$ & $\begin{array}{l}\text { No role of obesity in Prostate cancer } \\
\text { etiology. }\end{array}$ \\
\hline $\begin{array}{l}\text { Jonsson [12] } \\
(2003)\end{array}$ & Cohort & $\begin{array}{l}\text { Sweden } \\
21,884 \text { twins } \\
631 \text { Prostate cancer cases }\end{array}$ & BMI & No significant differences & $\begin{array}{l}\text { Obesity was found to be associated } \\
\text { with breast and uterine cancer, but not } \\
\text { prostate cancer. }\end{array}$ \\
\hline $\begin{array}{l}\text { Engeland [16] } \\
(2003)\end{array}$ & Cohort & $\begin{array}{l}\text { Norway } \\
950,000 \text { participants } \\
33000 \text { cases }\end{array}$ & $\begin{array}{l}\text { BMI } \\
\text { Height }\end{array}$ & $\begin{array}{l}\mathrm{RR}=1.09 \dagger * \\
\mathrm{RR}=1.72 \dagger\end{array}$ & $\begin{array}{l}\text { Modest association but the risk was } \\
\text { much higher in men who were obese at } \\
\text { age } 45 .\end{array}$ \\
\hline $\begin{array}{l}\text { Giovannucci [17] } \\
(2003)\end{array}$ & Cohort & $\begin{array}{l}\text { US. } \\
51,529 \text { participants } \\
2,896 \text { cases }\end{array}$ & BMI & $\begin{array}{l}\mathrm{RR}=0.52 \dagger P \text {-trends: }<0.001 \\
\text { (For age group }<60 \text { years) } \\
\mathrm{RR}=0.74 \text { (NS) } P \text { trends } 0.01 \\
\text { (For those with }+ \text { family history) }\end{array}$ & $\begin{array}{l}\text { Association significant only for men } \\
\text { with age }<60 \text { or }+ \text { family history. }\end{array}$ \\
\hline $\begin{array}{l}\text { Wright [18] } \\
(2007)\end{array}$ & Cohort & $\begin{array}{l}\text { US. } \\
\text { 287,760 participants } \\
\text { 9,986 Prostate cancer cases } \\
\text { 173 Prostate cancer deaths }\end{array}$ & BMI & $\begin{array}{l}\mathrm{RR}=0.67 \dagger \text { (Localized disease }) \\
\mathrm{RR}=2.12 \dagger \text { (Mortality) }\end{array}$ & $\begin{array}{l}\text { Obesity was found to be inversely } \\
\text { related to incident prostate cancer but } \\
\text { positively linked with Prostate cancer } \\
\text { mortality. }\end{array}$ \\
\hline $\begin{array}{l}\text { Rodriguez [21] } \\
(2005)\end{array}$ & Cohort & $\begin{array}{l}\text { US. } \\
69,991 \text { participants } \\
5,252 \text { cases }\end{array}$ & BMI & $\begin{array}{l}\mathrm{RR}=0.84 \text { (NS) } P \text {-trends: } 0.002 \\
\text { (Low grade Prostate cancer) } \\
\mathrm{RR}=1.22 \text { (NS) } P \text { trends } 0.03 \\
\text { (High grade Prostate cancer) } \\
\mathrm{RR}=1.54 \dagger P \text { trends } 0.05 \\
\text { (Stage D / Fatal Prostate cancer) }\end{array}$ & $\begin{array}{l}\text { Obesity was found to be inversely } \\
\text { related tolow-grade Prostate cancer but } \\
\text { positively associated with high grade } \\
\text { and fatal Prostate cancer. }\end{array}$ \\
\hline $\begin{array}{l}\text { Gong [20] } \\
(2006)\end{array}$ & Clinical trial & $\begin{array}{l}\text { US. } \\
10,258 \text { participants } \\
1,936 \text { cases }\end{array}$ & BMI & $\begin{array}{l}\mathrm{RR}=0.72 \dagger \\
\text { (Low grade Prostate cancer, age } \\
\geq 65) \\
\mathrm{RR}=1.56 \dagger \\
(\text { High grade Prostate cancer, age } \\
\geq 65 \text { ) }\end{array}$ & $\begin{array}{l}\text { Obesity increases risk of low-grade } \\
\text { Prostate cancer but increases the risk of } \\
\text { high-grade Prostate cancer }\end{array}$ \\
\hline $\begin{array}{l}\text { Porter [22] } \\
(2005)\end{array}$ & Case-control & $\begin{array}{l}\text { US. Washington } \\
753 \text { Prostate cancer cases } \\
703 \text { controls } \\
\text { Age } 40-64 \text { yr }\end{array}$ & $\begin{array}{l}\text { BMI } \\
\text { Weight } \\
\text { Height }\end{array}$ & $\begin{array}{l}\mathrm{OR}=0.77(\mathrm{NS}) . P \text {-trends: } 0.04 \\
\mathrm{OR}=0.74(\mathrm{NS}) P \text { trends } 0.03 \\
\mathrm{OR}=0.78(\mathrm{NS})\end{array}$ & $\begin{array}{l}\text { Obesity is inversely associated with } \\
\text { Prostate cancer in middle-aged men }\end{array}$ \\
\hline $\begin{array}{l}\text { Hsieh [13] } \\
(1999)\end{array}$ & Case-control & $\begin{array}{l}\text { Greece } \\
320 \text { cases, } 246 \text { controls }\end{array}$ & $\begin{array}{l}\text { BMI } \\
\text { Height }\end{array}$ & No significant differences & $\begin{array}{l}\text { No significant association between } \\
\text { obesity and Prostate cancer. }\end{array}$ \\
\hline $\begin{array}{l}\text { Friedenreich [14] } \\
(2004)\end{array}$ & Case-control & $\begin{array}{l}\text { US. Alberta } \\
988 \text { cases } \\
1063 \text { control }\end{array}$ & $\begin{array}{l}\text { BMI } \\
\text { Waist-hip ratio } \\
\text { Height }\end{array}$ & $\begin{array}{l}\mathrm{OR}=1.12(\mathrm{NS}) \\
\mathrm{OR}=1.07(\mathrm{NS}) \\
\mathrm{OR}=0.78(\mathrm{NS})\end{array}$ & $\begin{array}{l}\text { No significant associationbetween } \\
\text { anthropometric measures and Prostate } \\
\text { cancer }\end{array}$ \\
\hline
\end{tabular}

*BMI: Body Mass Index, RR: Relative Risk, NS= Not Significant, $\uparrow:$ significant, LBM: Lean Body Mass, PA: Physical Activity

incidence is inconclusive, there is strong evidence that suggests obesity is associated with prostate cancer aggressiveness and mortality. In fact, several large prospective studies examining this relationship in context with aggressiveness and stage of tumor and mortality rates deserve particular attention.

Recently three major prospective studies examined the association between prostate cancer and obesity by stage and grade of cancer. Wright et al. followed approximately 288,000 people in a prospective cohort study and reported obesity is inversely associated with localized prostate cancer but positively associated with higher mortality rates among those diagnosed with prostate cancer [18]. Rodriguez et al. in a cohort study of 69,991 men found those with high BMI are at increased risk of high-grade and fatal prostate cancer but less likely to be associated with low-grade prostate cancer [19]. Results from Prostate Cancer Prevention Trial (PCPT) were similar, among the 10,258 men undergoing biopsy they found obesity increases the risk of high-grade but decreases the risk of low-grade prostate cancer [20]. These findings are summarized in table 1 .
Studies examining the relation between prostate cancer and obesity have yielded inconsistent patterns related to high and lowgrade tumor, family history and age of diagnosis. However, all recent large prospective studies suggest obesity is associated with increased risk of high-grade prostate cancer but decreased risk of low-grade cancer. Reasons for this paradoxical pattern are unclear; some of the hypothesized explanations in literature are discussed below [21,22].

\section{Discussion}

Obesity can make prostate cancer detection more difficult at the time of screening and diagnostic testing. Several studies have reported obese men are likely to have lower prostate specific antigen (PSA) [2326]. Thus, using standard PSA values, obesity may make prostate cancer detection more difficult leading to delayed diagnosis. Studies have also suggested that obese men are likely to have larger prostate than nonobese men $[25,26]$. Larger prostate increases the likelihood of missing existing cancer on core biopsy [26,27]. Additionally, it is difficult to perform digital rectal exam in obese men, which can increase the 
chances of missing prostate cancer during physical examination [26].

Furthermore, obesity is associated with increased serum estrogen levels and decreased serum testosterone levels $[28,29]$. Several studies have reported low levels of serum testosterone associated with highgrade tumor at diagnosis $[30,31]$. A recent study suggests that higher serum testosterone levels are associated with increased risk of lowgrade prostate cancer but with decreased risk of high-grade prostate cancer [32]. These hypotheses may partly explain the differential association of obesity with subtypes of prostate cancer.

In addition to altered levels of androgen, obesity is associated with increased risk of diabetes [33], metabolic syndromes [34], increased levels of insulin, IGF-1 [34] and inflammatory mediators [35]. Studies have shown that diabetes is associated with reduced risk of prostate cancer [21,36], but metabolic syndrome is associated with increased risk of prostate cancer [37]. Increased levels of insulin [38] and IGF1 [39] have been linked to increased risks of prostate cancer. Several studies suggest that obesity through increased inflammatory cytokines contributes to prostate carcinogenesis [40,41].

In summary, above mentioned explanations supports the role of obesity as a risk factor for prostate cancer but adds complexity to an already confusing picture of obesity and prostate cancer association. The relationship between obesity and prostate cancer is complex and not yet completely understood. With the present epidemiological data supporting the presence of a complex association between obesity and prostate cancer, it is important that future research be directed towards better understanding this relationship. The use of BMI as a surrogate for obesity is debatable and more current anthropometric techniques for the measure of body fat should be considered. Factors such as environmental exposure and gene markers should be incorporated in the study design to assess gene-environmental interactions.

In lieu of recent research showing a differential association between obesity and subtypes of prostate cancer, it is important that more refined and detailed histological grading and staging should be used in the future research. With the evidence that obesity can make prostate cancer detection more difficult due to changes in PSA levels, increased prostate size and difficulties in performing digital rectal exam, it is clinically important that physicians take special care while performing examinations or doing diagnostic tests on obese men. Furthermore, with recent research consistently showing that obesity is associated with an aggressive disease and higher mortality rates, new treatment strategies in obese men with prostate cancer should be considered. Hopefully, a better understanding of the etiological heterogeneity of this complex association and appropriate interventions would help to reduce morbidity and mortality due to prostate cancer.

\section{References}

1. Flegal KM, Carroll MD, Ogden CL, Curtin LR (2010) Prevalence and trends in obesity among US adults, 1999-2008. JAMA 303: 235-241.[Crossref]

2. Li C, Ford ES, McGuire LC, Mokdad AH (2007) Increasing trends in waist circumference and abdominal obesity among US adults. Obesity (Silver Spring) 15: 216-224.[Crossref]

3. Mokdad AH, Ford ES, Bowman BA, Dietz WH, Vinicor F, et al. (2003) Prevalence of obesity, diabetes, and obesity-related health risk factors, 2001. JAMA 289: 76-79. [Crossref]

4. Lakka HM, Lakka TA, Tuomilehto J, Salonen JT (2001) Abdominal obesity is associated with increased risk of acute coronary events in men. Eur Heart $J$ 23: 706713.[Crossref]

5. Calle EE, Rodriguez C, Walker-Thurmond K, Thun MJ (2003) Overweight, obesity, and mortality from cancer in a prospectively studied cohort of U.S. adults. $N$ Engl J
Med 348: 1625-1638.[Crossref]

6. Jemal A, Siegel R, Xu J, Ward E (2010) Cancer statistics, 2010. CA Cancer J Clin 60: 277-300.[Crossref]

7. Nomura AM (2001) Body size and prostate cancer. Epidemiol Rev 23: 126-131. [Crossref]

8. MacInnis RJ, English DR (2006) Body size and composition and prostate cancer risk systematic review and meta-regression analysis. Cancer Causes Control 17: 989-1003. [Crossref]

9. Schuurman AG, Goldbohm RA, Dorant E, van den Brandt PA (2000) Anthropometry in relation to prostate cancer risk in the Netherlands Cohort Study. Am J Epidemiol 151: 541-549.[Crossref]

10. Habel LA, Van Den Eeden SK, Friedman GD (2000) Body size, age at shaving initiation, and prostate cancer in a large, multiracial cohort. Prostate 43: 136-143. [Crossref]

11. Lee IM, Sesso HD, Paffenbarger RS Jr (2001) A prospective cohort study of physical activity and body size in relation to prostate cancer risk (United States). Cancer Causes Control 12: 187-193.[Crossref]

12. Jonsson F, Wolk A, Pedersen NL, Lichtenstein P, Terry P, et al. (2003) Obesity and hormone-dependent tumors: cohort and co-twin control studies based on the Swedish Twin Registry. Int JCancer 106: 594-599.[Crossref]

13. Hsieh CC, Thanos A, Mitropoulos D, Deliveliotis C, Mantzoros CS, et al. (1999) Risk factors for prostate cancer: a case-control study in Greece. Int J Cancer 80: 699-703. [Crossref]

14. Friedenreich CM, McGregor SE, Courneya KS, Angyalfi SJ, Elliott FG (2004) Casecontrol study of anthropometric measures and prostate cancer risk. Int J Cancer 110 : 278-283.[Crossref]

15. Dal Maso L, Zucchetto A, La Vecchia C, Montella M, Conti E, et al. (2004) Prostate cancer and body size at different ages: an Italian multicentre case-control study. $\mathrm{Br} \mathrm{J}$ Cancer 90: 2176-2180.[Crossref]

16. Engeland A, Tretli S, Bjørge T (2003) Height, body mass index, and prostate cancer: a follow-up of 950000 Norwegian men. Br J Cancer 89: 1237-1242.[Crossref]

17. Giovannucci E, Rimm EB, Liu Y, Leitzmann M, Wu K, et al. (2003) Body mass index and risk of prostate cancer in U.S. health professionals. J Natl Cancer Inst 95: 12401244.[Crossref]

18. Wright ME, Chang SC, Schatzkin A, Albanes D, Kipnis V, et al. (2007) Prospective study of adiposity and weight change in relation to prostate cancer incidence and mortality. Cancer 109: 675-684.[Crossref]

19. Rodriguez C, Freedland SJ, Deka A, Jacobs EJ, McCullough ML, et al. (2007) Body mass index, weight change, and risk of prostate cancer in the Cancer Prevention Study II Nutrition Cohort. CancerEpidemiol Biomarkers Prev 16: 63-69.[Crossref]

20. Gong Z, Neuhouser ML, Goodman PJ, Albanes D, Chi C, et al. (2006) Obesity, diabetes, and risk of prostate cancer: results from the prostate cancer prevention trial Cancer Epidemiol Biomarkers Prev 15: 1977-1983.[Crossref]

21. Rodriguez C, Patel AV, Mondul AM, Jacobs EJ, Thun MJ, et al. (2005) Diabetes and risk of prostate cancer in a prospective cohort of US men. Am J Epidemiol 161: 147152.[Crossref]

22. Porter MP, Stanford JL (2005) Obesity and the risk of prostate cancer. Prostate 62 316-321.[Crossref]

23. Gray MA, Delahunt B, Fowles JR, Weinstein P, Cookes RR, et al. (2004) Demographic and clinical factors as determinants of serum levels of prostate specific antigen and its derivatives. Anticancer Res 24: 2069-2072.[Crossref]

24. Werny DM, Thompson T, Saraiya M, Freedman D, Kottiri BJ, et al. (2007) Obesity is negatively associated with prostate-specific antigen in U.S. men, 2001-2004. Cancer Epidemiol Biomarkers Prev 16: 70-76.[Crossref]

25. Fowke JH, Motley SS, Cookson MS, Concepcion R, Chang SS, et al. (2007) The association between body size, prostate volume and prostate-specific antigen. Prostate Cancer Prostatic Dis 10: 137-142.[Crossref]

26. Pruthi RS, Swords K, Schultz H, Carson CC 3rd, Wallen EM (2009) The impact of obesity on the diagnosis of prostate cancer using a modern extended biopsy scheme. $J$ Urol 181: 574-577.[Crossref]

27. Kranse R, Beemsterboer P, Rietbergen J, Habbema D, Hugosson J, et al. (1999) 
Predictors for biopsy outcome in the European Randomized Study of Screening for Prostate Cancer (Rotterdam region). Prostate 39: 316-322.[Crossref]

28. Kupelian V, Page ST, Araujo AB, Travison TG, Bremner WJ, et al. (2006) Low sex hormone-binding globulin, total testosterone, and symptomatic androgen deficiency are associated with development of the metabolic syndrome in nonobese men. $J$ ClinEndocrinolMetab91:843-850.[Crossref]

29. Pasquali R, Casimirri F, Cantobelli S, Melchionda N, MorselliLabate AM, et al. (1991) Effect of obesity and body fat distribution on sex hormones and insulin in men. Metabolism 40: 101-104.[Crossref]

30. Hoffman MA, DeWolf WC, MorgentalerA (2000) Is low serum free testosterone a marker for high grade prostate cancer? J Urology 163: 824-827.[Crossref]

31. Schatzl G, Madersbacher S, Thurridl T, Waldmüller J, Kramer G, et al. (2001) Highgrade prostate cancer is associated with low serum testosterone levels. Prostate 47: 52-58. [Crossref]

32. Platz EA, Leitzmann MF, Rifai N, Kantoff PW, Chen YC, et al. (2005) Sex steroid hormones and the androgen receptor gene CAG repeat and subsequent risk of prostate cancer in the prostate-specific antigen era. Cancer Epidemiol Biomarkers Prev 14: 1262-1269.[Crossref]

33. Ford ES, Williamson DF, Liu S (1997) Weight change and diabetes incidence: findings from a national cohort of US adults. Am J Epidemiol 146: 214-222.[Crossref]
34. Zimmet P, Alberti KG, Shaw J (2001) Global and societal implications of the diabetes epidemic. Nature 414: 782-787.[Crossref]

35. Greenberg AS, Obin MS (2006) Obesity and the role of adipose tissue in inflammation and metabolism. Am J ClinNutr 83: 461S-465S.[Crossref]

36. Zhu K, Lee IM, Sesso HD, Buring JE, Levine RS, et al. (2004) History of diabetes mellitus and risk of prostate cancer in physicians. Am J Epidemiol 159: 978-982. [Crossref]

37. Lund Håheim L, Wisløff TF, Holme I, Nafstad P (2006) Metabolic syndrome predicts prostate cancer in a cohort of middle-aged Norwegian men followed for 27 years. $\mathrm{Am} \mathrm{J}$ Epidemiol 164: 769-774.[Crossref]

38. Hsing AW, Chua S Jr, Gao YT, Gentzschein E, Chang L, et al. (2001) Prostate cancer risk and serum levels of insulin and leptin: a population-based study. J Natl Cancer Inst 93:783-789.[Crossref]

39. Kaaks R, Lukanova A, Sommersberg B (2000) Plasma androgens, IGF-1, body size, and prostate cancer risk: a synthetic review. Prostate Cancer Prostatic Dis 3: 157-172. [Crossref]

40. Nelson WG, De Marzo AM, DeWeese TL, Isaacs WB (2004) The role of inflammation in the pathogenesis of prostate cancer. $J$ Urol 172: S6-11.[Crossref]

41. Platz EA, De MarzoAM (2004) Epidemiology of inflammation and prostate cancer. $J$ Urol 171: S36-40.[Crossref]

Copyright: $\odot 2016$ Trivedi T. This is an open-access article distributed under the terms of the Creative Commons Attribution License, which permits unrestricted use, distribution, and reproduction in any medium, provided the original author and source are credited. 